\title{
THE INFLUENCE OF PLANNED BEHAVIOUR THEORY AND KNOWLEDGE TOWARDS THE WAQIF INTENTION IN CONTRIBUTING WAQF
}

\author{
Mochammad Maulana Alifiandy ${ }^{a}$ \\ Raditya Sukmana ${ }^{b}$ \\ a,b Department of Islamic Economics, Faculty of Economics and Business, \\ Universitas Airlangga \\ Email: maulanaalifiandy@gmail.comª ; raditya@feb.unair.ac.id ${ }^{b}$
}

\section{ARTICLE HISTORY}

Received:

16 October 2020

Revised:

12 November 2020

Accepted:

8 December 2020

Online available:

11 December 2020

Keywords:

Cash Waqf,

Planned Behavior

Theory,

Waqif,

Waqf Institution.

*Correspondence:

Name:

Raditya Sukmana

E-mail:

raditya@feb.unair.ac.id

\section{ABSTRACT}

Waqf performance, as part of Islamic social finance is determined by, among others, willingness of society to donate their assets into waqf. Ability to understand determinants of the willingness may contribute to more optimum waqf assets accumulation and management. This study aims to investigate the effect of attitudes, subjective norms, perceived behavioral control, and knowledge in influencing the willingness of waqif to donate through the Airlangga University Social Fund Management Center (PUSPAS). This research is a quantitative study using multiple regression analysis. Data for this study is obtained from 98 respondents. The study results imply that there was no significant simultaneous influence in the variables of attitudes, subjective norms, behavioral control, and knowledge of waqif willingness to represent in PUSPAS. The attitude and knowledge variables are variables that have a significant influence partially. In contrast, the subjective norm variables and behavioral control have a partially insignificant impact on the intention of waqf to represent.

\section{INTRODUCTION}

Higher education is one of the institutions with a high potential for the management of waqf. It is because the university has many students enrolled in different walks of life. Waqf can be trained through the university (Fadhilah et al., 2017) to all parts of the university itself, from students, student guardians, to university staff. The more people know the benefits of waqf, the higher the funds that can be raised.

In waqf development, many educational institutes have already managed waqf, either general waqf or productive waqf (Alhifni et al., 2017). As for Malaysia, at least five universities have already established their waqf-based university concept in their higher education operations; these involve welfare services and academic or professional programs and activities. These universities are the UPM (Putra University 
of Malaysia), the UKM (National University of Malaysia), the IIUM (International Islamic University of Malaysia), and the AIU (Albukhary International University, Malaysia) (Mahamood \& Ab Rahman, 2015).

The applications of waqf in higher education can be found in the management of IIUM endowment funds as a solution to overcome the lack of study funds to pay tuition fees through the establishment of the International Islamic University Malaysia's Waqf Fund (IIUMWF).

Table 1

Assessing the Efficiency of Monitoring the International Islamic University Malaysia's Waqf Fund (IIUMWF) Ratio 2003-2005

\begin{tabular}{lrrcc}
\hline \multicolumn{1}{c}{ Performance Efficiency Ratio } & $\mathbf{2 0 0 3}$ & $\mathbf{2 0 0 4}$ & $\mathbf{2 0 0 5}$ \\
\hline Program Expenses/Total & $33.33 \%$ & $69.82 \%$ & $35.77 \%$ \\
Investment Income/Average & $4.70 \%$ & $6.70 \%$ & $5.20 \%$ \\
Total Fundraising Expenses/Total Fundsraised & $3.30 \%$ & $1.70 \%$ & $*$ \\
\hline
\end{tabular}

The table explains that the IIUMWF calculates the recommended minimum percentage for spending on underprivileged student finance programs, 65\%, as suggested by Sorensen and Kyle (2007) only proven in 2004. Both the percentages 2003 and 2005 are well below 65\%. This low percentage can also be caused by not many students who need help paying tuition fees in 2003 and 2005, or it can also mean that the IIUMWF rates are too high.Therefore, the collection of donations, especially donations of funds, can be optimized by applying the Planned Behavior (TPB) theory. TPB will investigate the extent of waqf education received by waqif through knowledge (extensive knowledge that waqf is flexible), attitude towards behavior, subjective norms, and perceived behavioral control (Darmansyah et al., 2020). All these variables are necessary to determine to what extent people understand waqf and to what extent they want to do that waqf after getting to know information about waqf.

A philanthropic institution that applies cash waqf in the field of education in Indonesia is Airlangga University's Center for Social Fund Management (PUSPAS). PUSPAS is a social institution on behalf of Airlangga University and an institution that educates Muslim clerical staff and student guardians about the existence of waqf. PUSPAS introduces to the general public that waqf also can be donated by cash waqf. Waqf's educational process in having a decision and intention to fulfill waqf can be applied by assessing the level of knowledge, attitude towards subjective behavioral norms, perceived behavioral control, and motivation to comply. Through these four variables, we can check to what extent the community understands waqf in Islam.

This information leads the authors interested in conducting a study to find out how awareness (attitudinal factors, subjective norms, perceived behavioral control) and knowledge influence the willingness of the judiciary to represent at PUSPAS Universitas Airlangga. 


\section{LITERATURE REVIEW}

Waqf, according to Indonesian Waqf Act Number 41 year 2004, is defined as “... a legal act of wakif to separate and/or surrender part of one's assets to be used forever or for a certain period of time in accordance with their interests for worship and / or general welfare according to sharia. Waqf is derived from arabic term waqafa which etimologically means to hold and to prevent. Terminologically, waqf means the assets of Muslims that are intended to provide benefits (maslahah) ot public in general, while the principal is held in perpetuity. The Holy Quran does not specifically mention about waqf term. However, the Muslim scholars agree that perpetual charity (sadaqa jariyah) mentioned by the Prophet is equal to waqf.

There are some pillars of requirements of waqf: i) the donor of waqf (waqif); ii) the assets to be donated as waqf (mawquf); iii) the beneficiary of waqf (mawquf 'alaih); and iv) the waqf contract (sigat) (Taufiq, 2013). There are some benefits of introduction of waqf into the general public. First, waqf is reflection of care and responsibility values within the society, because waqf as a form of philanthropy if implemented shows reciprocal care among members of society. Second, moral support for the waqif, such that the spiritual benefits become eternal even after the demise of the waqif. Third, enlarge wealth accumulation that can be used for spending to support the needs of general public/ummah. Fourth, waqf can be source of fund that can support life quality improvement of the society through provision of health, education, income generation, etc.

Waqf is divided into two types, namely conventional waqf and cash waqf (Rusydiana \& Rahayu, 2019). These two types of waqf have differences in the objects they represent. In conventional waqf, usually the object that is waqf is an object with high value, for example land, a certificate of ownership of a building, and so on, whereas, in cash waqf, the object represented is cash. The Indonesian Council of Ulema (Majelis Ulama Indonesia/MUI), in its fatwa issued on May 11, 2002 regarding cash waqf, explains that the cash waqf is jawaz or permissible, on condition that it can only be distributed and used for things that are permitted by Islamic sharia and the principal value of the money waqf. sustainability must be guaranteed, cannot be sold, gifted, and / or inherited (Rusydiana, 2018).

\section{Theory of Planned Behavior}

The theory of Planned Behavior explains that the behavior of individuals arises from the intention to behave. Based on this theory, it can be seen that intention is formed by the attitude to behavior, subjective norm and perceived behavioral control owned by individuals (Khanifah et al., 2017). Consumer attitudes describe consumer trust in various attributes and benefits of the object, which is a consistent response, both positive and negative responses to the product (Pulungan et al., 2018). Shukor et al. (2017) prove that trust in awaqf institutions determines attitudes towards cash 
waqf. Consequently, awqaf institutions must develop confidence among endowers, leading to their positive attitude.

The subjective norm is the urge of someone to see whether or not social events are involved in the incident. Subjective norms are a person's perception of social pressure to show behavior or not. According to Marhaini (2009), in this theory, a person's behavior depends on intention, then intention to behave depends on attitude and subjective norms. The items tested in subjective norms (religious teachers, parents, spouses, siblings, friends, relatives, and neighbors) are compared those tested under attitude construct. The result found a significant influence on the behavioral intentions of Muslim employees to contribute to cash waqf from employment income (Pitchay et al., 2015).

The last part is behavioral control, which means that someone feels that something is easy or difficult to do. Controlling a person's behavior can change depending on the circumstances and the type of behavior to be performed. If someone feels that something is easy to go through, the intensity of someone doing it will increase. Research conducted by Putraa and Isfandayani (2020) implies that the Behavioral Control variable is the most dominant sufficient contribution value influencing the cash intention variable.

Besides, knowledge is the full use of information and data that is equipped with the potential skills, competencies, ideas, intuition, dedication, and motivation of the people involved. The holistic view assumes that knowledge exists in different ideas, decisions, talents, root causes, relationships, perspectives, and concepts (Mustika et al., 2019). Knowledge about waqf is generally understood as a form of sadaqah, which will benefit the contributor or endower in the hereafter life. It is believed that extensive knowledge and understanding of waqf, specifically cash waqf, might encourage waqif to contribute. (Shukor et al., 2017).

In general, the intention is considered to be an individual indication of what someone will do in the future. Thus, a person's purpose is their desire or plan to take action in question at a point in the future. Because intention presents information about the future direction, attitudes, beliefs, and intentions usually adjust over time. (Samsuri et al., 2019). The intention is interpreted as an individual's intention to conduct behavior-based on attitudes toward behavior, subjective norms, and perceptions of behavioral control (Palallo et al., 2019).

Whereas three determinants are determined the intention to behave, such as Behavioral beliefs, individual beliefs about the results of behavior, and evaluation of these results (beliefs strength and outcome evaluation). Secondly, Normative beliefs, assumptions about normative expectations of people others, and motivation to fulfill these expectations (normative beliefs and motivation to comply). Last, Control beliefs, beliefs about the existence of things that support or inhibit the behavior that will be displayed (control beliefs) and perceptions about how strong things which help and inhibit the behavior (perceived power) (Panjaitan et al., 2018). 
Several factors that motivate the Muslims to donate their property for the interest of Islamic education had been identified. Some of the elements are to find their intentions, to spread the Islamic religion, no heir, and to encourage economic development. (Azha et al., 2013).

\section{RESEARCH METHOD}

This research approach uses a quantitative approach. Exogenous variables in this study are the Theory of Planned Behavior (Seniwati et al., 2019), which includes attitudes (attitude to behavior), knowledge (subjective), subjective norms, and perceived behavioral control (perceived behavioral control). The endogenous variable $(Y)$ is the intention (Surya et al., 2018) that influences waqf's decision to distribute waqf funds at PUSPAS Airlangga University. Meanwhile, the independent variables utilized in this study are attitude towards behavior (X1), knowledge (X2), subjective norms (X3), perceived behavioral control (X4).

Types and sources of data used in this study, namely primary data and secondary data. Primary data was obtained from the results of the dissemination of questionnaires (Fianto et al., 2019) provided to waqf who conducted cash waqf in Surabaya with statements on the variables in the study. Secondary data has been obtained from the Internet, journals, and other literatures related to this study.

The population of this study is 4129 employees of Airlangga University. To find the sampling size requirement, slovin formula is utilized:

$n=\frac{N}{1+N e^{2}}$.

with $\mathrm{n}$ is the required sampling size, $\mathrm{N}$ is the number of population (4129 individuals), and e is limit of error tolerance, which is in this study is set at 0.1. Above calculation shows that this study needs about 98 respondents as sampling size requirement.

Data from 98 respondents are calculated manually to find out the percentage of statements in the questionnaire. Respondents are waqif in Airlangga University's PUSPAS. PUSPAS is chosen in this study because its unique position as first university based waqf institution in Indonesia. Calculated respondent data is presented in a simple table consisting of rows and columns to facilitate the location of data collection points (Arikunto, 2010). A validity test is used to measure the validity of a questionnaire. Questionnaires are valid if the questionnaire's questions can reveal something measured by the survey according to what researchers expected (Ghozali, 2016). Then the reliability test is performed to see the truth of the measurement data so that it is reliable, the definition of reliability. The questionnaire is reliable if the respondent's responses are consistent with statements from time to time (Ghozali, 2016).

The next stage is multiple regression analysis (Shah et al., 2019), a prediction of the rise and fall of the dependent variable determined by changes in at least two independent variables. $F$ test is performed to calculate the value of $F$ arithmetic to 
compare with the value of $\mathrm{F}$ table, while the formula for calculating the value of $\mathrm{F}$ arithmetic is (Sugiyono, 2014):

$\mathrm{F}=\frac{\mathrm{R}^{3} / \mathrm{k}}{\left(1-\mathrm{R}^{2}\right) /(\mathrm{n}-\mathrm{k}-1)}$

The t-test is a test used on the dependent variable and two or more independent variables in part or separately, assuming the other independent variables are considered constant (Sugiyono, 2014).

$\mathrm{t}=\frac{\mathrm{r} \sqrt{\mathrm{n}-2}}{\sqrt{1-\mathrm{r}^{2}}}$

\section{RESULT AND ANALYSIS}

\section{Profile of PUSPAS}

The Center for Social Fund Management (Pusat Pengelolaan Dana Sosial/PUSPAS) is a philanthropic institution that is officially formed and managed by Airlangga University. The inauguration of PUSPAS as a social institution that can manage waqf funds was legalized by the Indonesian Waqf Board (BWI) on 23 August 2018 (Rifa'i, 2018).

Universitas Airlangga has started to introduce cash waqf to the wider community with the main focus of cash waqf management carried out by PUSPAS is charity donations and endowments. There are about $60 \%$ of waqf funds channeled by PUSPAS for financial investment activities and $40 \%$ for real sector development activities such as canteens and libraries. The PUSPAS target in promoting cash waqf is for education, research, event operations and community service (Deswari, 2019).

\section{Descriptive Statistics}

The following table shows the descriptive statistics of variables utilized in this study.

Table 2

Descriptive Statistics of Varibles

\begin{tabular}{lccccc}
\hline & N & Minimum & Maximum & Mean & Std. Deviation \\
\hline X1 & 98 & 11.00 & 20.00 & 16.7653 & 2.01950 \\
X2 & 98 & 6.00 & 21.00 & 15.8367 & 2.72330 \\
X3 & 98 & 14.00 & 28.00 & 20.6939 & 3.12426 \\
X4 & 98 & 21.00 & 36.00 & 27.8571 & 3.29010 \\
Y & 98 & 8.00 & 16.00 & 11.4286 & 1.78770 \\
Valid N (listwise) & 98 & & & & \\
\hline
\end{tabular}

Source: Processed Data

Table 2 above shows that the minimum value of each indicator in the attitude variable $\left(X_{1}\right)$ is 11 with a maximum value of 20 . The value of the average attitude indicator score is 16.76 percent, greater than the standard deviation of 2.019. This shows that there is a small fluctuation in the movement of the attitude variable $\left(X_{1}\right)$. 
The mean value of the subjective norm variable $\left(X_{2}\right)$ is 15.83 , which is greater than the standard deviation of 2.7 , this indicates that the fluctuation of changes in the subjective norm variable $\left(X_{2}\right)$ is small. The maximum value of the questionnaire data is 21 with a minimum value of 6 . The minimum value of the behavior control variable $\left(X_{3}\right)$ is 14 with a maximum value of 28 . The mean value is the same as the previous variable which is greater than the standard deviation of 20.6 and 3.12. The minimum value of the knowledge variable $\left(X_{4}\right)$ is 21 and the maximum value is 36 . The mean value of 27.8 is still greater than the standard deviation value of 3.29 so the level of fluctuation in the knowledge variable $\left(\mathrm{X}_{4}\right)$ is small. Furthermore, the intention variable $(\mathrm{Y})$ in this study shows a minimum value of 8 and a maximum value of 16 . The value of the mean 11.4 is still greater than the standard deviation value of 1.78 so the level of fluctuation in the intention variable $(\mathrm{Y})$ is small.

\section{Results}

The following is the test results of multiple regression analysis showing the value of the equation between exogenous variables followed by a constant value based on table 3 below:

Tabel 3

Multiple Regression Results

\begin{tabular}{lcc}
\multicolumn{3}{c}{ Tabel 3 } \\
& Multiple Regression Results \\
\hline Variable & Coefficients (B) & p-value \\
\hline (Constant) & 0.439 & 0.297 \\
X1 & 0.304 & $0.006^{*}$ \\
X2 & 0.048 & 0.617 \\
X3 & 0.096 & 0.323 \\
X4 & 0.326 & $0.008^{*}$ \\
\hline *denotes significance at 95\% level of confidence
\end{tabular}

Source: Processed Data

\section{Relationship between Attitude and Willingness of The Waqif in Representation}

Attitude variable $\left(X_{1}\right)$ is found to have coefficient score of 0.304 with $p$-value 0.006 , lesser 0.05 . It means, attitude significantly affects cash waqf intention of respondents through PUSPAS.

According to Airlangga University's CFO:

"... in my opinion, the variable asked also is different types of knowledge, income is important. It is simply not filled in because they think it is confidential ".

"... The income he receives if the income is large is more open to releasing."

The statement indicates that in determining whether or not they agree to comply with the cash waqf, the respondent's attitude may also be influenced by the salary they receive so that it is likely that the higher the person's salary, the greater the desire to increase the cash waqf. 
A person's attitude depends on the beliefs emphasized by individuals who can represent what he has received or felt, and attitudes can explain more than 50 percent of the types of intentions that vary, the more positive a person's attitude, the higher the intention to do something. The number of respondents who agree with the attitude question shows that the higher the respondents' intention to implement cash waqf through the PUSPAS institution.

\section{Relationship of Subjective Norms to The Waqif's Will to Represent}

The test results show that the value of the coefficient is 0.048 with $p$-value of 0.617 , meaning it is higher than 0.05 , it can be interpreted that subjective norms do not affect the gift intention when fulfilling cash through PUSPAS Universitas Airlangga. Several previous studies have shown that attitudes, individual standards, and quality of service have no significant effect on having a positive and significant value on a person's intention to pay cash (Nuraini et al., 2018). Subjective norms only offer positive relationships at the same time, but not partially. The presence or absence of the knowledge variable as an additional variable still yields data that is not significant with a significance level of 0.244 . Subjective standards in this study are determined based on each individual's willingness to pay the cash for the income they have received. This description is following Airlangga University's financial staff statement as follows:

"... or a factor of confidence too, so he channeled his zakat through other institutions..."

The statement explains that social standards in the implementation of zakat in the environment of staff and teachers are free to do anywhere, not limited to PUSPAS institutions at Airlangga University, but can also be conducted at other institutions' that they desire.

\section{Relationship of Perceived Behavioral Control to Waqif's Intention to Represent}

The results of the study indicate that behavioral control has a significant value higher than 0.05 , i.e., $0.617(0.617>0.05)$, indicating that the behavioral rule variable $\left(X_{3}\right)$ has no effect on the waqif willingness to represent, so $\mathrm{HO}$ is accepted and $\mathrm{H} 1$ is rejected. Behavioral control that is prescribed can produce two kinds of components, namely belief control, the perception of a belief about difficulty, and understanding of power that explains the opinion to bring about such behavior (Yogatama, 2013). Behavioral control observed in this study belongs to the observational force, where waqif tries to bring out the behavior in him to show whether he can export cash or not.

The answers to the results of the questionnaire showed that the respondents had a great deal of knowledge about the presence of waqf institutions. Fifty percent of respondents disagreed with the statement of waqf institutions that are still hard to find. A staggering 59 percent replied that agreeing to the presence of PUSPAS at Airlangga University would provide convenience to respondents' cash waqf. It means 
that while many respondents were aware of the existence of PUSPAS as an institution that officially manages waqf funds, respondents were still reluctant to pay cash waqf through PUSPAS. This statement is reinforced by the observation made in the results of the interview with the Director of Finance and the financial staff of Airlangga University as follows:

"... deduction for infaq only per month, group four Rp10,000, group three $\mathrm{Rp} 5,000$, group two and group one $\mathrm{Rp} 2,000$..."

"I was following the implementation on my first day on duty. If all the civil servants were treated this way in the past and the last period, they were all put here, for five years, only 2 or 3 faculties deposited here would be faculty itself can be managed ..."

Based on the above statement, we can understand that in fact, employees registered as a civil servant (PNS) have filed salary deductions for compulsory infaq turned in to Airlangga University financial center. Despite in the past five years, activity started to get out of hand because only 2-3 faculties only routinely manage staff and teacher deductions for infaq. The deduction level for infaq is group 1 to $2 \mathrm{Rp} 2,000$,

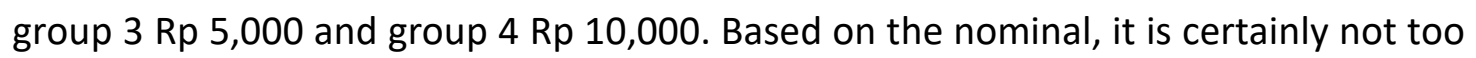
big, but the behavioral control that drives teachers and lecturers into infaq is still low.

\section{Knowledge Relationship with Waqif Willingness to Represent}

The test results from the study indicate that knowledge has the t-statistical value of 2,690 with a significance level of 0.008 , meaning that $0.008<0.05$, which caused $\mathrm{H} 4$ is accepted. There is a mutually influential relationship between knowledge and the intention of the future waqf to represent. The factors influencing waqf's readiness for a future waqf based on the highest order are the level of religiosity, generosity, knowledge of cash waqf, financial situation, recommendations of subjective norms and services (Nuraini et al., 2018). The results of the partial test of this study are relevant to those conducted by Mokhtar because knowledge provides a positive value and a positive level of significance that influences the willingness of the future waqf to represent.

The questionnaire results show that the majority of respondents are aware of waqf, which is illustrated by the question, "I know that waqf is a mandatory worship service for all Muslims." The results of the questionnaire showed that 46 percent answered, followed by 24 percent; the rest replied strongly disagreeing. The majority of respondents agreed to several questions related to understanding the type of capital goods which can benefit the economy. The capital potential is immense, capital goods have the same laws as zakat and PUSPAS at Airlangga University as a legitimate institution for capital goods. 
The fact that the majority of respondents already know a lot about waqf is not accompanied by the willingness of the respondents to be a potential waqf in PUSPAs, this is reinforced by a statement by Mr. Ardianto as Managing Director of Finance to the Airlangga University:

"Actually, this is different, and this is happiness. Thus, he considers the deduction of waqf pieces even though we don't apply waqf pieces, so those who assume they have been cut because they don't know between infaq shodaqoh or waqf they don't know. Therefore, actually there is no piece of waqf. "

The above statement shows that TSI staff and teachers only understand that there is a deduction of shodaqoh and mandatory infaq. As previously explained, deductions for infaq and alms salaries are divided into three groups. It causes the respondents' feeling that the deductions for infaq are equal to the deductions for cash waqf. So, cash waqf funds can still not be collected optimally, even though the respondents consist of tendon staff, and teachers already have sufficient knowledge about the waqf itself.

\section{CONCLUSION}

Based on the analysis, we can conclude that attitude has a positive and significant effect on the willingness of waqif in cash representation at PUSPAS Airlangga University so that $\mathrm{H} 1$ is accepted. Respondents' attitudes to performing waqf depend on the salary they receive and how much the respondent is willing to enforce waqf. Then the subjective norm variable has no significant impact on the waqif's willingness to have a money representation at PUSPAS Airlangga University. A large number of respondents responses disagreed with the questionnaire questions, which indicated that the encouragement in the social environment of the trend staff and teachers is still not willing to provide waqif in cash representation at PUSPAS. Behavioral control indicates that value, which is not significant in influencing waqif, will give money to PUSPAS Airlangga University. It does not matter also supported by the results of the questionnaire found that many respondents disagreed with the questions asked, and in any case, the faculties that deposit money salary deduction for infaq and alms.

Finally, knowledge has a significant effect on the willingness of waqif in cash representation at Airlangga University's PUSPAS until H1 is accepted. Many respondents have sufficient understanding of waqf to stimulate further the desire to pay cash waqf, but according to the CFO of Airlangga University, this has not been practiced by staff and teachers. This study has limitations, so further research is recommended to study further any factors affecting the community's willingness to become more familiar with cash waqf. New research may also consider optimizing the 
cash waqf for teachers and educators, but all levels of society at Airlangga University. It is expected that the implications for the government and donations as a more authorized party can be introduced more widely so that the optimization of the cash waqf collection can be achieved.

\section{REFERENCES}

Alhifni, A., Huda, N., Anshori, M., \& Trihantana, R. (2017). WAQF an instrument of community empowerment in Islamic Boarding School Daarut Tauhiid in Indonesia. Journal of Islamic Economics, Banking and Finance, 13(2), 76-88.

Arikunto, S. (2010). Prosedur Penelitian Suatu Pendekatan Praktik. Rineka Cipta.

Azha, L., Baharuddin, S., Sayurno, Salahuddin, S. S., Afandi, M. R., \& H., H. A. (2013). The Practice and Management of Waqf Education in Malaysia. Procedia - Social and Behavioral Sciences, 90(InCULT 2012), 22-30. https://doi.org/10.1016/j.sbspro.2013.07.061

Darmansyah, D., Fianto, B. A., Hendratmi, A., \& Aziz, P. F. (2020). Factors determining behavioral intentions to use Islamic financial technology: Three competering models. Journal of Islamic Marketing, ahead-of-p(ahead-of-print). https://doi.org/10.1108/JIMA-12-2019-0252

Deswari, Z. A. (2019). PUSPAS UNAIR Kenalkan Wakaf Tunai kepada Peserta Student Exchange Thailand. http://news.unair.ac.id/2019/03/29/puspas-unair-kenalkanwakaf- tunai-kepada-peserta-student-exchange-thailand/

Fadhilah, A. A., Zurina, S., Mohammad, A., \& Nursilah, A. (2017). The effort of selected public and private universities to develop Awqaf property in Malaysia. Pertanika Journal of Social Sciences and Humanities, 25(Special Issue), 267-280.

Fianto, B. A., Gan, C., \& Hu, B. (2019). Financing from Islamic microfinance institutions: evidence from Indonesia. Agricultural Finance Review, 79(5), 633-645. https://doi.org/10.1108/AFR-10-2018-0091

Ghozali, I. (2016). Aplikasi Analisis Multivariete Dengan Program IBM SPSS 23. UNIVERSITAS DIPONEGORO.

Khanifah, Anam, M. C., \& Astuti, E. B. (2017). Pengaruh Attitude Toward Behaviour, Subjective Norm, Perceived Behavioral Control Pada Intention Whistleblowing. Jurnal Akses, 12(24), 147-158.

Mahamood, S. M., \& Ab Rahman, A. (2015). Financing universities through waqf, pious endowment: is it possible? Humanomics, 31(4), 430-453. https://doi.org/10.1108/H-02-2015-0010

Marhaini. (2009). Analisis Perilaku Konsumen Dalam Pembelian Komputer Merek Acer (Studi Kasus: Mahasiswa Fakultas Ekonomi Universitas Sumatera Utara). Jurnal Manajemen Bisnis, 2(1), 1-6.

Mustika, H., Eliyana, A., \& Agustina, T. S. (2019). Antecedents of knowledge sharing behaviour. International Journal of Innovation, Creativity and Change, 8(2), 5771.

Nuraini, I., Takidah, E., \& Fauzi, A. (2018). Faktor-Faktor Yang Mempengaruhi Intensi Dalam Membayar Wakaf Uang Pada Pegawai Kantor Wilayah Kementerian Agama Provinsi Dki Jakarta. Jurnal Universitas Majalengka, 1(2), 97-108.

Palallo, U. D., Syafar, M., Amiruddin, R., Indar, \& Yani, A. (2019). Effects of adolescent attitudes on forming intention to stop smoking. International Journal of 
Innovative Technology and Exploring Engineering, 9(1), 1026-1030. https://doi.org/10.35940/ijitee.A4634.119119

Panjaitan, H., Tarmizi, Daulay, M., \& Ginting, R. (2018). Effect of awareness against taxpayers tax compliance, small and medium enterprises in medan. International Journal of Civil Engineering and Technology, 9(9), 465-475.

Pitchay, A. A., Meera, A. K. M., \& Saleem, M. Y. (2015). Factors influencing the behavioral intentions of muslim employees to contribute to cash-waqf through salary deductions. Journal of King Abdulaziz University, Islamic Economics, 28(1), 63-100. https://doi.org/10.4197/Islec.28-1.3

Pulungan, D., Fauzi, A., \& Rini, E. S. (2018). The effect of product innovation, consumer attitude and advertising at the purchase decision of yamaha motorcycle in $\mathrm{cV}$ sejati mitra motor medan marelan. International Journal of Scientific and Technology Research, 7(12), 222-226.

Putraa, P., \& Isfandayani. (2020). Planned behavior theory in paying cash waqf. International Journal of Psychosocial Rehabilitation, 24(4), 5669-5676. https://doi.org/10.37200/IJPR/V24I4/PR201662

Rifa'i, F. F. (2018). UNAIR Jadi Universitas Pertama yang Kelola Dana Wakaf. http://news.unair.ac.id/2018/08/24/unair-jadi-universitas-pertama-yang- keloladana-wakaf/)

Rusydiana, Aam S, \& Rahayu, S. S. (2019). Bagaimana Strategi Pengembangan Wakaf Tunai di Indonesia? Jurnal Ekonomi Dan Bisnis Islam, 5(1), 15-33.

Rusydiana, Aam Slamet. (2018). Aplikasi Interpretive Structural Modeling untuk Strategi Pengembangan Wakaf Tunai di Indonesia. Jurnal Ekonomi Dan Bisnis Islam, 4(1), 1-17.

Samsuri, A., Ismiyanti, F., \& Narsa, I. M. (2019). The effects of risk tolerance and financial literacy to investment intentions. International Journal of Innovation, Creativity and Change, 10(6), 280-294.

Seniwati, Pulubuhu, D. A. T., Sutinah, Rahmatia, \& Alhaqqi, M. S. (2019). Planned behaviour theory for the science agency: The role of youth for sustainable waste management. 343(1). https://doi.org/10.1088/1755-1315/343/1/012101

Shah, S. A. A., Sukmana, R., Fianto, B. A., Ahmad, M. A., Usman, I. U., \& Mallah, W. A. (2019). Effects of Halal social media and customer engagement on brand satisfaction of Muslim customer: Exploring the moderation of religiosity. Journal of Islamic Marketing, 2000. https://doi.org/10.1108/JIMA-06-2019-0119

Shukor, S. A., Anwar, I. F., Aziz, S. A., \& Sabri, H. (2017). Muslim attitude towards participation in cash WAQF: Antecedents and consequences. International Journal of Business and Society, 18(S1), 193-204.

Sorensen, S. M., \& Kyle, D. L. (2007). Valuable Volunteers. Strategic Finance, February, 39-45.

Sugiyono. (2014). Metode Penelitian Kuantitatif, Kualitatif, dan R\&D. ALFABETA CV.

Surya, E. D., Ginting, P., Rini, E. S., \& Absah, Y. (2018). The analysis of Halal tourism products and brand image destination on tourists' repeated visits via trust in West Sumatera Province. International Journal of Civil Engineering and Technology, 9(8), 1206-1220.

Taufiq, T. (2013). Wakaf dalam Persepektif Hukum Islam. Jurnal IImu Pengetahuan Dan Teknologi, 24(1), 62-75.

Yogatama, L. A. M. (2013). Analisis pengaruh attitude, subjective norm, dan perceived 
behavior control terhadap intensi penggunaan helm saat mengendarai motor pada remaja dan dewasa muda di jakarta selatan. Jurnal Elektronik Universitas Gunadarma, 5, 8-9. https://doi.org/10.1109/T-SU.1985.31645 